\title{
Radiological Evaluation of the Effects of Printing Parameters on 3D Printed Cylindrical LW-PLA
}

Samples: Preliminary Results

3 Boyutlu Baskı Parametrelerinin Silindirik LW-PLA Baskıları Üzerindeki Etkilerinin Radyolojik

Değerlendirmesi: ilk Bulgular

İsmail Özsoykal', R. Buğra Hüsemoğlu², Ayşegül Yurt'

'Dokuz Eylul University, Health Sciences Institute, Medical Physics Department, Izmir, Turkey.

${ }^{2}$ Dokuz Eylul University, Institute of Health Sciences, Department of Biomechanics, Izmir, Turkey

Abstract

Purpose: In this study, it is aimed to evaluate the radiological tissue equivalency of different 3D printed samples obtained at different printing temperatures, flow rates and infill rates.

Materials and Methods: Ultimaker 3 Extended 3D printer and LW-PLA filament were used witin the scope of this study. A total of 18 cylinders were printed by using 3 different printing temperatures of $195^{\circ} \mathrm{C}, 200 \mathrm{oC}$ and $205 \mathrm{oC}, 3$ different flow rates of $60 \%, 80 \%$ and $100 \%$, and 2 different infilling rates of $90 \%$ and $100 \%$. Each sample is obtained $1 \mathrm{~cm}$ in diameter and $3 \mathrm{~cm}$ in height. After calculating the densities of the samples, they were imaged by a Philips Brilliance 128-slice computed tomography scanner. In the images, the average Hounsfield Unit values and the standard deviations of these values were recorded at 5 different axial positions for each sample. The mean $\mathrm{HU}$ and standard deviation values recorded over 5 slices were evaluated according to the printing parameters.

Results: Density of the samples are obtained between $0.63 \mathrm{~g} / \mathrm{cm} 3$ and $1.19 \mathrm{~g} / \mathrm{cm} 3$. It was observed that the density of the samples were directly proportional to the flow rate and the infill rate. In addition, the average Hounsfield Unit values of the samples varied between -450 and +73 . On the other hand, the standard deviation values were recorded between \pm 6 and \pm 25 . It was observed that the mean Hounsfield Unit values increased with increasing temperature, flow rate and infill rate. The standard deviation values decreased with increasing printing temperatures.

Conclusion: Considering the mean Hounsfield Unit values of different tissues imaged in routine computed tomography examinations, it is concluded that the samples obtained at different printing parameters using LW-PLA filament may have radiological properties that can represent many soft tissues. Keywords: Computed tomography, 3D printer, radiology

Özet:

Amaç: Bu çalışmada 3 boyutlu yazıcıyla farklı sıcaklıklarda, akış oranlarında ve dolgu oranlarında elde edilen örnek baskıların radyolojik özellik bakımından doku eşdeğerliklerinin değerlendirilmesi amaçlanmmıştır.

Gereç ve Yöntem: Çalışma kapsamında Ultimaker 3 Extended marka 3 boyutlu yazıcı ve LW-PLA filament kullanılmıştır. 195oC, 200oC ve 205oC olmak üzere 3 farklı baskı sıcaklığı, $\% 60, \% 80$ ve $\% 100$ olmak üzere 3 farklı akış oranı ve $\% 90$ ile $\% 100$ olmak üzere 2 farklı dolgu oranı kullanılarak toplamda 18 silindir baskı elde edilmiştir. Her bir baskı $1 \mathrm{~cm}$ çapında ve $3 \mathrm{~cm}$ boyundadır. Elde edilen baskıların yoğunlukları hesaplandıktan sonra Philips Brilliance marka 128 kesitli bilgisayarlı tomografi cihazında görüntüleri alınmıştır. Görüntülerde her bir baskıya ait 5 farklı kesitte ortalama Hounsfield Unit değerleri ve bu değerlerin standart sapmaları kaydedilmiştir. 5 kesit üzerinden alınan ortalama HU ve standart sapma değerleri baskı parametrelerine göre değerlendirilmiştir.

Bulgular: Elde edilen baskılara ait yoğunluk değerleri $0.63 \mathrm{~g} / \mathrm{cm} 3$ ile $1.19 \mathrm{~g} / \mathrm{cm} 3$ arasındadır. Yoğunluk değerlerinin akış oranı ve dolgu oranıyla doğrudan ilişkili olduğu gözlenmiştir. Baskılara ait ortalama Hounsfield Unit değerlerinin ise -450 ile +73 arasında değiştiği gözlenmiştir. Buna karşılık standart sapma değerleri ise \pm 6 ile \pm 25 arasında kaydedilmiştir. Ortalama Hounsfield Unit değerlerinin artan sıcaklık, akış oranı ve dolgu oranıyla arttığı gözlenmiştir. Standart sapma değerlerinin ise artan baskı sıcaklıklarında azaldığı gözlenmiştir.

Sonuç: Rutin bilgisayarlı tomografi incelemelerde görüntülenen farklı dokulara ait ortalama Hounsfield Unit değerleri düşünüldüğünde, LW-PLA filamenti kullanılarak farklı baskı parametrelerinde elde edilen örneklerin birçok farklı yumuşak dokuyu temsil edebilecek radyolojik özelliklere sahip olabileceği sonucuna ulaşılmıştır.

Anahtar kelimeler: Bilgisayarlı tomografi, 3 boyutlu yazıcı, radyoloji

Correspondence Address : İsmail Özsoykal,

ORCID ID of the author: I.Ö 0000-0002-5812-9347, R.B.H

Dokuz Eylul University, Institute of Health

0000-0003-1979-160X, A.Y. 0000-0001-9898-2329

Sciences, Medical Physics Department Izmir,

Turkey ozsoykal@gmail.com

Please cite this article in press at: Özsoykal I., Hüsemoğlu R.B.,Yurt A., Radiological Evaluation of the Effects of Printing Parameters on 3D Printed Cylindrical LW-PLA Samples: Preliminary Results, Journal of Medical Innovation and Technology, 2021; 3 (2):28-34 doi: 10.51934/jomit.1037540 


\section{Introduction}

The latest advances in 3D printing technology, including bioprinting, have provided significant contributions to various fields of medical research and practice $(1,2)$. Direct clinical use of 3D printing methods is mainly related to the manufacture of patient specific surgical models, prostheses or even biological tissues. On the other hand, there is an increasing effort to adopt 3D printing technology in radiology and radiation oncology departments for the development of important tools that would help to improve the clinical practice.

Radiology and radiation oncology departmets are equipped with various test objects, named as phantoms, which are used periodically to quantify, evaluate and optimize the performance of imaging (e.g. computed tomography) or radiation therapy (e.g. linear accelerator) devices. By the use of phantoms, image quality or dosimetric accuracy analysis for various irradiation procedures could be carried out without any patient exposed to radiation. Recent studies focus on the use of $3 \mathrm{D}$ printing methods such as stereolithography (SLA) or fused deposition modeling (FDM) in the manufacture of various imaging or dosimetry phantoms $(3,4)$.

There are some benchmarks related to the design and manufacture of an imaging or dosimetry phantom. Radiological tissue equivalency, for example, is one of the main targets to accomplish. In order to mimick any part of the body, phantom material is expected to be very similar to a tissue or different tissues of interest, in terms of radiation attenuation properties. Radiological tissue equivalency of phantoms can be analyzed by means of Hounsfield Unit (HU) values obtained in computed tomography (CT) images. Every pixel which builds up a CT image has a HU value which is an indicator of radiation attenuation coefficient of the imaged object. In a CT image, $\mathrm{HU}$ values range from -1024 to +3071 for most CT scanners but almost all tissues have $\mathrm{HU}$ values between -1000 and +1000 which change depending mostly on the physical density of the tissues (figure 1) $(5,6)$.

There is a number of studies that analyzed the radiological properties of various 3D printed objects (7-18). These studies commonly reported that the physical density and the resulting $\mathrm{HU}$ value for a $3 \mathrm{D}$ printed object could be modified in two ways, using another filament with different density or changing the infill rate for the printed object. By the date these studies were carried out, other printing parameters such as printing temperature or flow rate have had no influence on the density of the filament at the nozzle outlet. However, for the upcoming years, filament manufacturers started to produce special filaments that are much more sensitive to printing temperature and flow rate which made it possible for the users to reduce the density of a printed object, without reducing the infill rate, by almost 3 times the original filament density.

This study aims to use one of these special filaments and to investigate the influence of printing temperature, flow rate and infill rate on physical density and corresponding $\mathrm{HU}$ value of 3D printed objects.

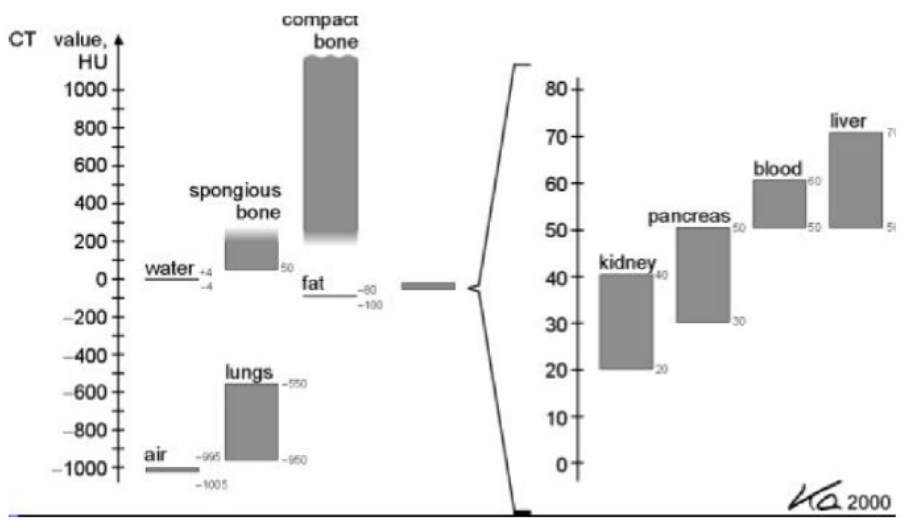

Figure 1. Illustration of the $\mathrm{HU}$ values for different tissues in human body (5).

\section{Materials and Methods}

\section{D Printing of Samples}

In this study, low weight polylactic acid (LW-PLA) based filament (Colorfabb, LW-PLA, Belfeld, Netherlands) was used to print 18 cylindrical samples which were identical in geometry ( $10 \mathrm{~mm}$ diameter and $30 \mathrm{~mm}$ height). Cylindrical models have been sliced in Cura which is a $3 \mathrm{D}$ printing slicer software for FDM printing. Ultimaker 3 Extended 3D printer was used to obtain the samples (figure 2). The samples were obtained in different printing temperature $\left(195^{\circ} \mathrm{C}, 200^{\circ} \mathrm{C}, 205^{\circ} \mathrm{C}\right)$, flow rate $(\% 60, \% 80, \% 100)$ and infill rate $(\% 90, \% 100)$ settings while all other basic printing parameters were held constant as shown in table 1.

Table 1. Print settings for 18 different cylindrical samples which were printed at 3 different printing temperature, 3 different flow rate and 2 different infill rate settings.

\begin{tabular}{|l|l|}
\hline \multicolumn{1}{|c|}{ Print Settings } & \multicolumn{1}{c|}{ Adjusted Value } \\
\hline Printing Temperature $\left({ }^{\circ} \mathrm{C}\right)$ & $195,200,205$ \\
\hline Flow Rate (\%) & $60,80,100$ \\
\hline Infill Rate (\%) & 90,100 \\
\hline Infill Pattern & Grid \\
\hline Nozzle Diameter (mm) & 0.4 \\
\hline Layer Thickness (mm) & 0.2 \\
\hline Printing Speed (mm/s) & 50 \\
\hline Fan Speed (\%) & 50 \\
\hline
\end{tabular}




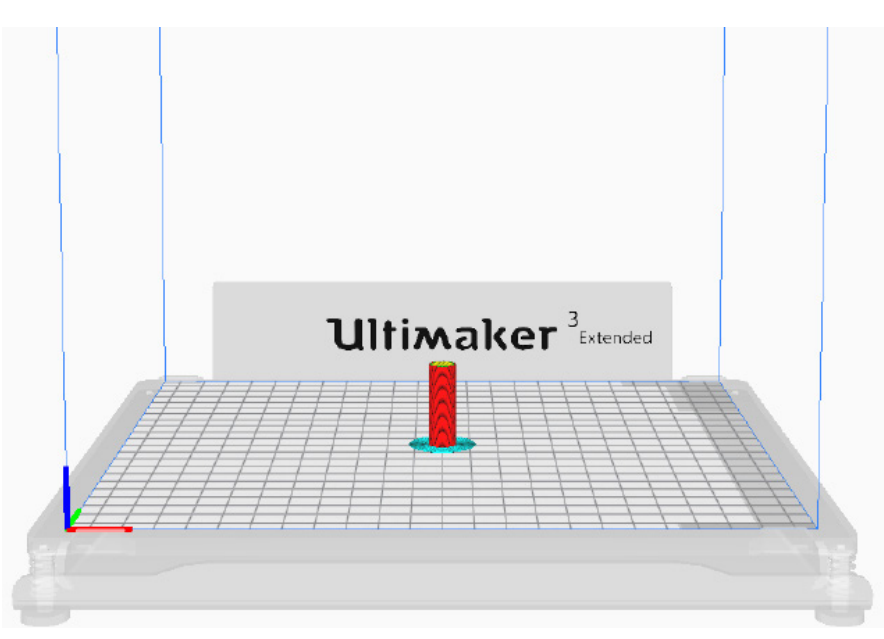

Figure 2: Cylindrical sample which was sliced in Cura software prior to printing in Ultimaker 3 Extended 3D printer.

\section{Physical Density Measurements and Computed Tomography Scan}

Physical densities of the printed samples have been determined prior to CT scan. For this purpose, mass and volume of each sample have been measured and calculated by using a microbalance (U.S. Solid, Model USS-DBS00008, Ohio, USA) with a sensitivity of $10-4$ grams and a micrometer (Insize Digital Caliper, Model 1112- 200, Suzhou, China) with a sensitivity of $10-3 \mathrm{~cm}$. Then, the samples were placed in a specialized holder which has been stabilized on a polymethylmetacrylate (PMMA) block (figure 3).
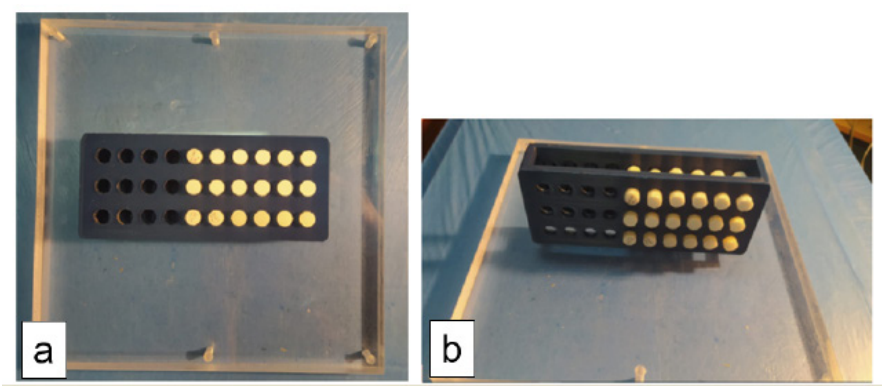

Figure 3: (a)18 cylindrical samples in a holder on a PMMA block and (b) CT imaging setup.

CT scan parameters were selected as shown in table 2 . This setup is one of the most frequently used protocols for routine clinical scans. The scanner used for the imaging procedure was Philips Brilliance 128 slice CT scanner which is located in the radiology department of Dokuz Eylul University Research and Application Hospital.

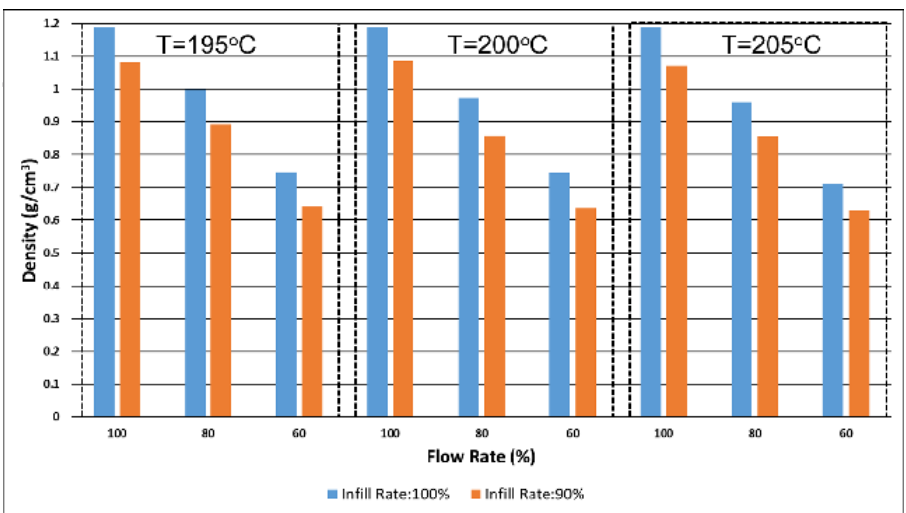

Hounsfield Unit (HU) Analysis of Printed Samples

CT image data has been loaded to imQuest which was developed by Duke University as a practical tool for CT image analysis and made available online (19). Image analysis has been performed over axial slices obtained along the longitudinal axis of cylindrical objects (figure 4). Mean HU values and standard deviation (STD) in HU values have been collected at 5 different positions along the longitudinal ( $\mathrm{z}$ ) axis by drawing circular regions of interest (ROIs) into the central portion of each cylindrical object. In addition, another ROI has been located inside the PMMA block which is assumed to be an adequately homogeneous medium to act as a reference for the evaluation of STD observed in printed samples.

Overall mean HU and STD values for each printed sample have been determined by taking the average of the 5 values collected over 5 different axial measurements. Mean $\mathrm{HU}$ values were used to interpret the radiological property of the sample and STD values were used to evaluate the homogeneity of printed samples.

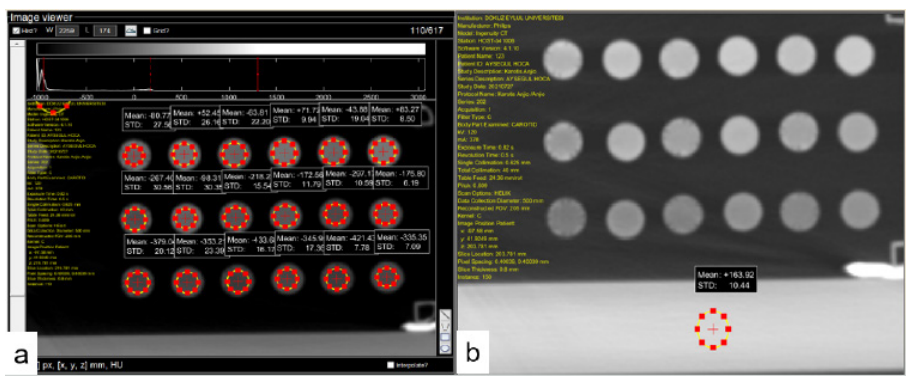

Figure 4: Axial CT images obtained for the measurement of mean $\mathrm{HU}$ and standard deviation (STD) values within ROls of (a) 18 different cylindrical samples and (b) PMMA block. 


\section{Results}

\section{Physical Density Results of Printed Samples}

Figure 5 illustrates the results obtained for physical densities of LW-PLA cylinders printed in this study. In general, the samples are found to have different densities ranging between $0.63 \mathrm{~g} / \mathrm{cm} 3$ and $1.19 \mathrm{~g} / \mathrm{cm} 3$. Reduction in flow rate and infill rate were observed to result in lower density prints. Furthermore, it is observed that the ratio of decrease observed in the density of samples was very similar to the ratio of reduction in flow rate and infill rate. That is to say, a $20 \%$ decrease in flow rate resulted in $20 \%$ decrease in density of the printed object. The same relationship is valid for the infill rate as well. On the other hand, printing temperature did not seem to have an influence on physical density as strong as other parameters, since the change is observed to be negligible between $195^{\circ} \mathrm{C}$ and $205^{\circ} \mathrm{C}$.

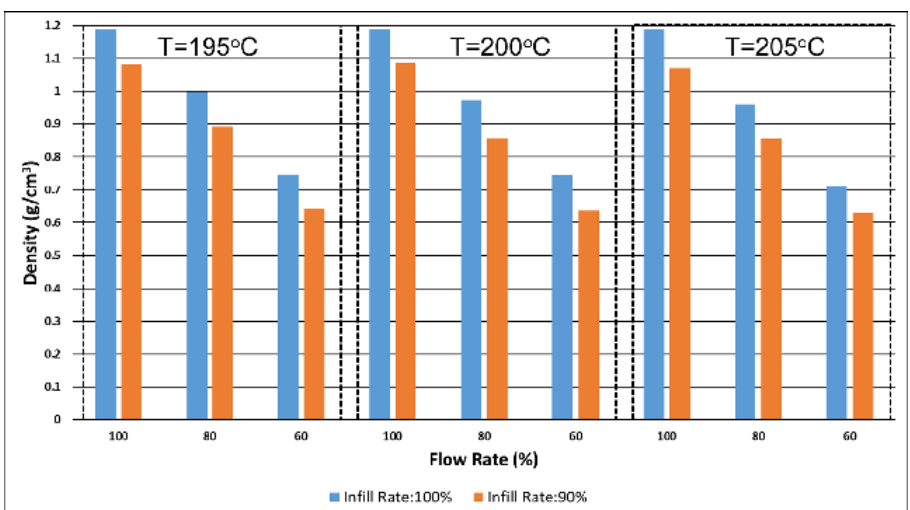

Figure 5: Physical densities of LW-PLA samples printed at different temperatures, flow rates and infill rates.

\section{Hounsfield Unit Analysis of the Samples: Mean HU values and Standard Deviation}

Results of mean HU and STD values for the printed samples are given in both table 3 and figure 6 . The mean HU values were measured between $-450 \mathrm{HU}$ and $+73 \mathrm{HU}$, while STD values were measured between $\pm 6 \mathrm{HU}$ and $\pm 25 \mathrm{HU}$. In addition, STD value of PMMA block has been measured as $\pm 12 \mathrm{HU}$.

These results indicated that, increasing printing temperature results in an increase in mean $\mathrm{HU}$ for all print settings except for $60 \%$ flow rate. On the other hand, STD values were observed to decrease with increasing temperature, regardless of infill rate or flow rate selection. When the flow rate is reduced, mean $\mathrm{HU}$ values of the samples exhibited a considerable decrease, similar to the effect observed when reducing the infill rate. STD values, in addition, are observed to increase with reducing infill rate, at $100 \%$ flow rate and all printing temperatures. However, at lower flow rates such as $80 \%$ and $60 \%$ it is observed that the influence of infill rate on the STD values diminished, regardless of printing temperature.

Table 3: Mean HU and STD values of cylindrical samples that are printed at different temperature, flow rate and infill rate settings.

\begin{tabular}{|c|c|c|c|c|c|c|}
\hline Printing Temperature $\left({ }^{\circ} \mathrm{C}\right)$ & \multicolumn{6}{|c|}{195} \\
\hline Flow Rate (\%) & \multicolumn{2}{|c|}{100} & \multicolumn{2}{|c|}{80} & \multicolumn{2}{|c|}{60} \\
\hline Infill Rate (\%) & 100 & 90 & 100 & 90 & 100 & 90 \\
\hline Mean HU( \pm STD) & $39( \pm 20)$ & $-90( \pm 25)$ & $-185( \pm 22)$ & $-287( \pm 14)$ & $-345( \pm 15)$ & $-450( \pm 14)$ \\
\hline Printing Temperature $\left({ }^{\circ} \mathrm{C}\right)$ & \multicolumn{6}{|c|}{200} \\
\hline Flow Rate (\%) & \multicolumn{2}{|c|}{100} & \multicolumn{2}{|c|}{80} & \multicolumn{2}{|c|}{60} \\
\hline Infill Rate (\%) & 100 & 90 & 100 & 90 & 100 & 90 \\
\hline Mean HU( \pm STD $)$ & $59( \pm 7)$ & $-80( \pm 15)$ & $-176( \pm 11)$ & $-252( \pm 15)$ & $-345( \pm 12)$ & $-450( \pm 11)$ \\
\hline Printing Temperature $\left({ }^{\circ} \mathrm{C}\right)$ & \multicolumn{6}{|c|}{205} \\
\hline Flow Rate (\%) & \multicolumn{2}{|c|}{100} & \multicolumn{2}{|c|}{80} & \multicolumn{2}{|c|}{60} \\
\hline Infill Rate (\%) & 100 & 90 & 100 & 90 & 100 & 90 \\
\hline Mean $\mathrm{HU}( \pm \mathrm{STD})$ & $73( \pm 6)$ & $-60( \pm 13)$ & $-140( \pm 7)$ & $-232( \pm 7)$ & $-328( \pm 7)$ & $-442( \pm 7)$ \\
\hline
\end{tabular}

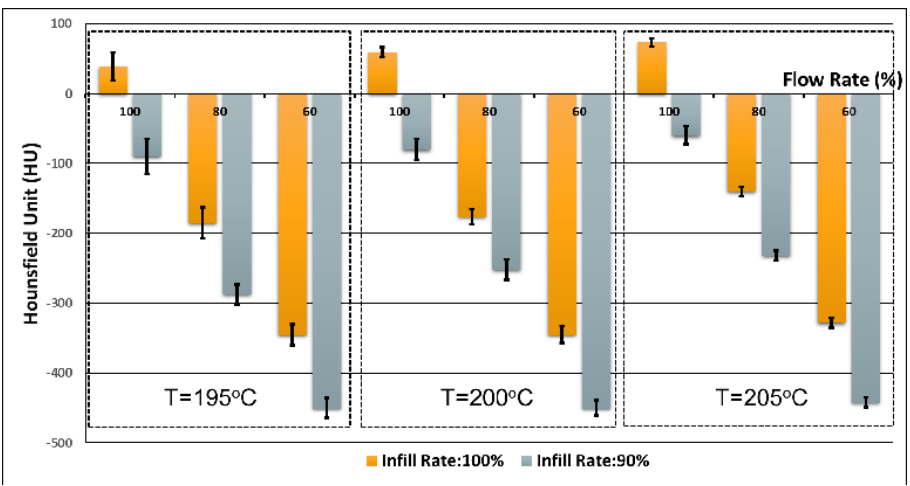

Figure 6: Mean HU and STD values of cylindrical samples printed at different temperature, flow rate and infill rate settings.

\section{Discussion}

3D printing is a promising technology for a wide range of scientific research. In radiolgy and radiation oncology, adoption of 3D printed tools to help improve clinical practice is an emerging field especially for the last decade $(3,4)$. Phantoms are one of these tools which are used commonly and frequently in the quality control tests of the imaging or radiotherapy modalities. These tests focus on image quality and/or dosimetric accuracy provided by the equipment. For a phantom to be used as such a test tool, it is important to be radiologically tissue equivalent and homogenious.

There are various types of filaments that are used in FDM based 3D printing such as acrylonitrile butadine styrene (ABS), thermoplastic polyurethane (TPU), polylactic acid 
(PLA) and high impact polystyrene (HIPS). In addition, some composite filaments that include wood, steel, copper or brass are recently available, widening the advantages of 3D printing for users. Most of these filaments have been used in the studies on radiological properties of $3 \mathrm{D}$ printed objects and it is shown that they can cover a range of $\mathrm{HU}$ values to correspond to different tissues (7-18). However, as a drawback, those filaments all had specific densities that can not be modified by printing process, i.e. does not change with printing parameters such as temperature and flow rate. The only way to modify density and therefore radiation attenuation property of a printed object is to change the infill rate or the filament itself. Infill rate, however, is not a favorable parameter to modify physical density of a printed object. The reason is that as the infill rate decreases, the distance between any adjecent lines increases and this leads to inhomogeneities in the printed structure which could be beyond the limits to mimick any tissue. Recently, new kind of special filaments are introduced that allow the modification of density of the filament at the nozzle outlet by adjusting printing temperature and flow rate. Such filaments are commercially available since 2019, and to our knowledge, there is not any study published yet in the literature regarding the evaluation of these filaments for radiological purposes. This study is important to introduce the effects of different print settings on the printed objects in terms of radiological tissue equivalency.

The results of this study indicated that the physical density of a printed sample changes depending on all of the three printing parameters. It is shown that the physical density could be reduced approximately by half with the proper selection of print settings (figure 5). Furthermore, it is reported by the manufacturer that it could be reduced by even one third of the original density which is approximately between $1.21 \mathrm{~g} / \mathrm{cm} 3$ and $1.43 \mathrm{~g} / \mathrm{cm} 3$. Among all printing parameters, minimum rate of change in density is observed due to printing temperature which is set between $1950 \mathrm{C}$ and $205 \mathrm{oC}$. Actually, it is stated by the manufacturer that the foaming, process by which the reduction in density becomes significant, starts at $215 \mathrm{oC}$. Thus, it can be understood that, below $2150 \mathrm{C}$, the changes in physical density due to printing temperature could be insignificant. Nevertheless, increasing temperature had some significant effects on the mean HU and STD values of the samples as shown in table 3 and figure 6. Especially at high flow rates such as $100 \%$ and $80 \%$, it is observed that the samples exhibited a significant increase in mean HU and decrease in STD as a result of higher printing temperature. This could not be due to foaming, but expansion, that can occur increasingly at higher temperatures and lower the volume of air gaps within the sample, thus increasing both the mean $\mathrm{HU}$ value and homogeneity (i.e. lower STD) of the printed object.

It is not interesting to observe that the rate of change in physical density has followed to the rate of change in flow rate and infill rate, since both parameters, differently from printing temperature, directly determines the amount of mass that would be deposited in the printed sample. On the other hand, when the influence of these parameters on mean $\mathrm{HU}$ is considered, it is observed that mean $\mathrm{HU}$ decreases with reduction in both flow rate and infill rate. STD values, in addition, seem to exhibit a higher margin of difference between different infill rates at $100 \%$ flow rate, regarding all printing temperatures. However, this difference due to infill rate is observed to diminish, in other words, the homogeneity of the samples became independent of infill rate, as the flow rate became lower. It is also reasonable to state that at high flow rates, the influence of printing temperature on mean HU and STD values are stronger. However at low flow rates this influence becomes insignificant especially for the mean $\mathrm{HU}$ values.

In a CT image, different tissues correspond to different HU values ranging between -1000 and +1000 in general. For example, mean $\mathrm{HU}$ value is -1000 for air gaps such as nasal cavity and pharynx and around -800 for lungs. For fat and soft tissues it ranges between -70 to +40 , and it is around +1000 for bones or calcified lesions(6). In this study, we obtained cylindrical samples between $+73 \mathrm{HU}$ and $-450 \mathrm{HU}$ which means that soft tissues such as liver, kidneys, pancreas, stomach, heart and vascular structures could be mimicked. In addition, our results indicated that further reduction in the flow rate and infill rate or increase in printing temperature could help printing samples equivalent to lungs.

In addition to mean HU value, STD value is an important parameter that indicates the homogeneity of the structures in an image. Most tissues have a homogeneous structure with STD values reported to vary between $10 \%$ $20 \%$ of the mean HU value (6). STD values of the samples printed in this study were in well agreement with this percentage values, except for the samples obtained at $1950 \mathrm{C}$ and $100 \%$ flow rate. In addition, most of the samples are found to have homogeneities even better than PMMA block. These results suggests the use of 3D printing as a safe tool to design and manufacture of high quality test phantoms for the evaluation of image quality for CT scanners. 
There are some limitations to this study. First of all, only one sample was printed per print setting which limited the evaluation of the 3D printing reproducibility and statistical analysis of the results. 5 different axial measurements were taken per sample to overcome this limitation. In addition, samples were obtained from a single 3D printer and a single filament spool. Engagement of multiple printers and multiple spools in the study would contribute to the reproducibility of the results. Another limitation is that the homogeneity of the printed samples was evaluated over the axial planes of the image. However, longitudinal (along the $z$ axis of cylinders) variation should also be considered to assure the stability for the entire volume of the sample. The last limitation is about the range of printing temperature and infill rate used to get the samples. Both parameters meight be extended (i.e. printing temperature can be increased upto $2600 \mathrm{C}$ or infill rate can be reduced to lower percentages) to evaluate the results with a wider spectrum of data.

Despite the limitations mentioned above, this study has revealed some notable results. Above all, it is shown that most of the soft tissues could be mimicked by using only one type of filament as a printing material, rather than using a variety of filaments with different densities. Moreover, the influence of the printing temperature and flow rate on both mean $\mathrm{HU}$ and STD values is proven to be valueable. Infill rate, on the other hand, is still a helpful print setting to modify density, however it is not very useful when considered by itself, especially due to increasing inhomogeneities at low printing temperatures for which no expansion or foaming of filament is triggered.

\section{Conclusion}

This study investigated the use of a special filament to obtain radiologically tissue equivalent objects with different densities and radiation attenuation properties. The preliminary results indicated that most of the soft tissues can be mimicked by modifying print settings such as printing temperature, flow rate and infill rate.

\section{Acknowledgements}

This study is part of a project which is financially supported by 1005 - National New Ideas And New Products Research Funding Program, TUBITAK. The authors hereby appreciate this opportunity they are provided with. 


\section{References}

1. Tamay DG, Usal TD, Alagoz AS, Yucel D, Hasirci D, Hasirci V. 3D and 4D Printing of Polymers for Tissue Engineering Applications. Frontiers in Bioengineering and Biotechnology 2019;7:164.

2. C. Lee Ventola. Medical Applications for 3D Printing: Current and Projected Uses. P T. 2014;39(10):704-11.

3. Tino R, Yeo A, Leary M, Brandt M, Kron T. A Systematic Review on 3D-Printed Imaging and Dosimetry Phantoms in Radiation Therapy. Technol Cancer Res Treat. 2019; 18:1533033819870208.

4. Filippou V, Tsoumpas C. Recent advances on the development of phantoms using 3D printing for imaging with CT, MRI, PET, SPECT, and ultrasound. Med Phys. 2018;45(9):e740-60.

5. Kalender WA. Computed tomography: fundamentals, system technology image quality, applications. 3rd edition, Paris: Publicis, 2011.

6. Kamalian S, Lev MH, Gupta AR. Handbook of Clinical Neurology, Neuroimaging Part 1.In: Computed tomography imaging and angiography - principles. Amsterdam: Elsevier, 2016:3-20.

7. Kairn T, Crowe SB, Markwell T. Use of 3D Printed Materials as Tissue-Equivalent Phantoms. In: Jaffray D. (eds) World Congress on Medical Physics and Biomedical Engineering. 2015:728-31.

8. Leng $S$, Chen B, Vrieze $T$, et al. Construction of realistic phantoms from patient images and a commercial threedimensional printer. J. Med. Imag. 2016;3(3): 033501-1-7.

9. Shin J, Sandhu RS, Shih G. Imaging Properties of 3D Printed Materials: Multi-Energy CT of Filament Polymers. J Digit Imaging. 2017;30(5):572-5.

10. Joerner MR, Maynard MR, Rajon DA, Bova FJ, Hintenlang DE. Three-Dimensional Printing for Construction of TissueEquivalent Anthropomorphic Phantoms and Determination of Conceptus Dose. AJR. 2018;211(6):1283-90.
11. Alssabbagh M, Tajuddin AA, Abdulmanap M, Zainon R. Evaluation of 3D printing materials for fabrication of a novel multifunctional 3D thyroid phantom for medical dosimetry and image quality. Rad Phys Chem. 2017;135:106-12.

12. Alssabbagh $M$, Tajuddin AA, Abdulmanap $M$, Zainon R. Evaluation of nine 3D printing materials as tissue equivalent materials in terms of mass attenuation coefficient and mass density. Int. j. adv. appl. sci. 2017;4(9):168-73.

13. Seoung YH. Evaluation of Usefulness for Quality Control Phantom of Computed Tomography Produced by Using Fused Deposition Modeling 3D Printing Technology. JEAS. 2017;12(12):3137-41.

14. Craft DF, Kry SF, Balter F, Salehpour M, Woodward W, Howell RM. Material matters: Analysis of density uncertainty in 3D printing and its consequences for radiation oncology. Med phys. 2018;45(4):1614-21.

15. Zhang $F$, Zhang $H$, Zhao $H$, et al. Design and fabrication of a personalized anthropomorphic phantom using 3D printing and tissue equivalent materials. Quant Imaging Med Surg. 2019;9(1):94-100.

16. Giron IH, Harder JM, Streekstra GJ, Geleijns J, Weldkamp WJH. Development of a 3D printed anthropomorphic lung phantom for image quality assessment in CT. Phys Med. 2019;57:47-57.

17. Solc J, Vrba T, Burianova L. Tissue-equivalence of 3D-printed plastics for medical phantoms in radiology. JINST. 2018; 13 P09018.

18. Assemany LPF, Junior OR, Silva E, Potiens MPA. Evaluation of $3 \mathrm{D}$ printing filaments for construction of a pediatric phantom for dosimetry in CBCT. Rad Phys Chem. 2020;167:108227.

19. imQuest, https://deckard.duhs.duke.edu/ samei/tg233. html. Date of Access:16.12.21 